International Journal of Physical Sciences and Engineering
Available online at http://sciencescholar.us/journal/index.php/ijpse
Vol. 2 No. 3, December 2018, pages: $36 \sim 42$
e-ISSN : 2550-6943, p-ISSN : 2550-6951
https://doi.org/10.29332/ijpse.v2n3.181

\title{
Web-based Speed Monitoring Tools
}

\author{
CrossMark \\ S. Poniman a, I Wayan Supardi b, Ni Wayan Dewi Mahayani c, Made Dwi Artawan d, \\ I Wayan Wisnawa Saputra ${ }^{\mathrm{e}}$
}

Article history: Received 2 April 2018, Accepted: 1 September 2018, Published: 14 September 2018

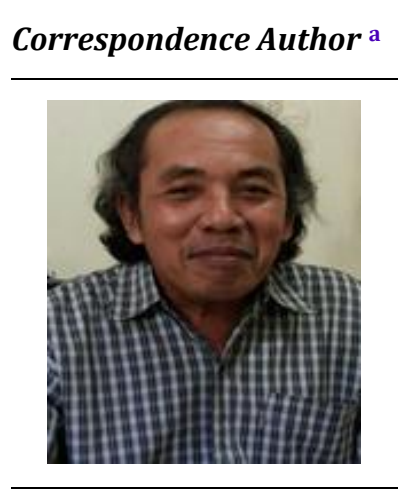

Keywords

Anemometer;

ATmega328;

DHT11;

Microcontroller;

SIM800L;

\begin{abstract}
The development of communication technology and science in this globalization era is very rapid. In utilizing this technology using laptops and the internet using Web as a means to monitor wind speed data in real-time. Wind measurement using an anemometer is a field from the weather forecasting agency by making an intermediary tool similar to the one on the weather forecast station using a simple anemometer that is connected to the laptop as a data observer. Anemometer or cup type wind sensor that has 3 cup counter wind speed gauges. In addition to using wind sensors, it is also needed ATmega328 microcontroller, SIM800L, and DHT11 sensors. Besides being able to measure wind speed in real time this tool can also measure air temperature and humidity. Wind speed measurement data can be accessed through a database and web that can be accessed on a server computer.
\end{abstract}

e-ISSN: 2550-6943, p-ISSN: 2550-6951 ๑Copyright 2018. The Author. SS Journals Published by Universidad Técnica de Manabí. This is an open-access article under the CC BY-SA 4.0 license (https://creativecommons.org/licenses/by-sa/4.0/) All rights reserved.

\section{Contents}

Abstract 36

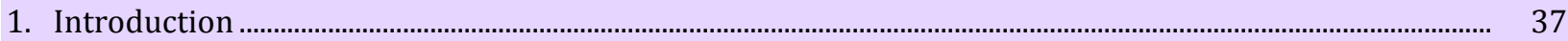

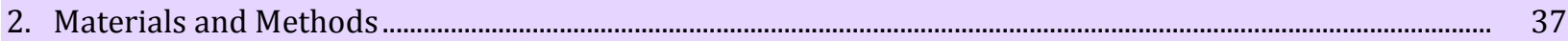

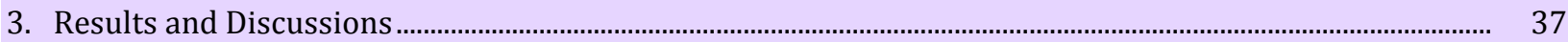

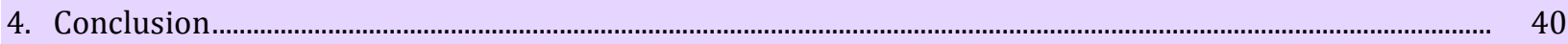

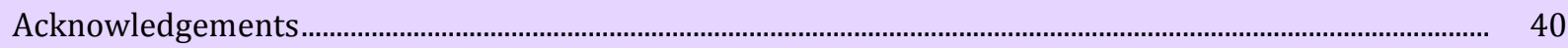

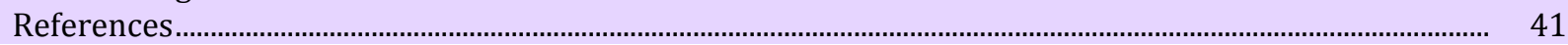

a Department of Physics, Udayana University, Bali, Indonesia

b Department of Physics, Udayana University, Bali, Indonesia

c Department of Physics, Udayana University, Bali, Indonesia

d Department of Physics, Udayana University, Bali, Indonesia

e Department of Physics, Udayana University, Bali, Indonesia 


\section{Introduction}

Wind is the flow of air in large numbers caused by the rotation of the earth and also because of the difference in the surrounding air pressure. The wind moves from a high-pressure air to a lower air pressure. Wind speed measurement can be measured using wind speed measuring devices. The wind speed measuring instrument that is usually used is an anemometer (Sawita, et al., 2005). The anemometer used is a type of cup that has 3 propellers (Utama, 2016; Fatoni, et al, 2015).

The utilization of this wind speed monitoring tool is expected to monitor wind speed in real time. With WEB and SIM800L so that maximum wind speed monitoring is possible. In addition to measuring wind speed, this tool can also monitor air temperature and humidity in real time. The design of this WEB-based wind speed monitoring tool is expected to help the community in providing information about wind speed, temperature and humidity in certain areas in real time (Saputro \& Wibawanto, 2017; Azlinaa, 2013).

\section{Materials and Methods}

Cup anemometer is a device used to measure the rate of wind where the wind rate sensor consists of three cups connected by an arm attached to the edges. All cups face in one circular direction so that when the wind blows the rotor rotates in a fixed direction (Hadi, et al., 2018). This tool responds to the dynamic style that comes from the wind that works on the device. The dynamic force of the wind on the cup concave surface is greater than the convex surface of the cup. The axis rotation of the cup system is connected mechanically or electronically with a device called a signal generator, for recording purposes. This signal generator is around counter (Palupi, 2006). For Anemometers that have three cups can be seen in Figure 1 (Hidayat, 2015).

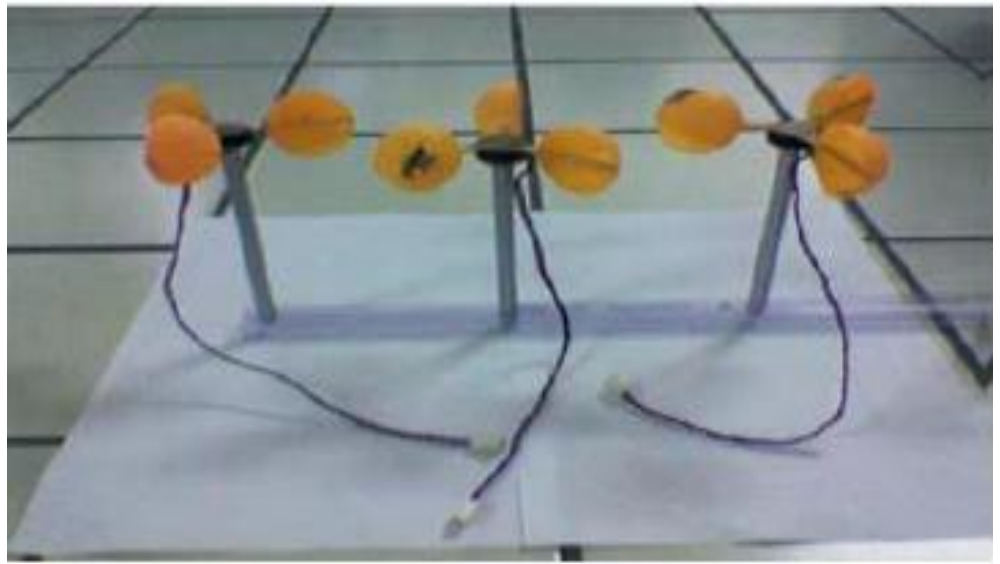

Figure 2.1 Cup anemometer (Hidayat, 2015)

\section{Results and Discussions}

The design results from the tools obtained from this study are as shown in Figure 2.

Poniman, S., Supardi, I. W., Mahayani, N. W. D., Artawan, M. D., \& Saputra, I. W. W. (2018). Web-based speed monitoring tools. International Journal of Physical Sciences and Engineering, 2(3), 36-42. 


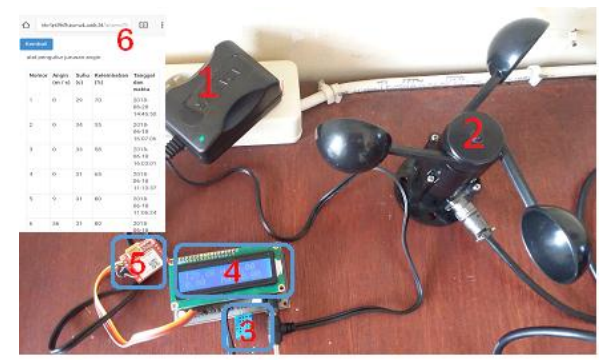

Figure 2. Wind speed monitoring tool with an anemometer, measuring temperature and humidity using DHT11 sensor and SIM800L module based on ATmega328 microcontroller

The functions of the section in Figure 4.1 are as follows.

a) Adapter serves as a voltage source.

b) Wind sensor QS-FS serves to measure wind speed.

c) Sensor DHT11 serves to measure the temperature and humidity of the air.

d) The minimum range of ATmega328 systems and Liquid Crystal Display (LCD), functions for data processing of wind sensor output voltage and DHT11 and LCD functions as a viewer of measured wind speed, temperature, and humidity.

e) The SIM800L circuit serves as the sender of wind speed, temperature, and humidity data measured to the server.

f) Display data on wind speed, temperature, and humidity in the android application on the smartphone serves to monitor data measured by design tools.

The data on the programmed anemometer on the ATmega328 microcontroller is also connected to the World Wide Web (WEB). Thus it can make it easier for users to monitor wind speed by opening the WEB to check wind speed data in real time.

\section{Software}

The program used in the design of the tool in this study uses the Arduino software built-in program, which combines $\mathrm{C}++$ and Java languages. Following are the initialization sub-programs as follows:
\#include < LiquidCrystal.h>
//\#include "SIM900.h"
//\#include "sms.h"
\#include $<$ SoftwareSerial.h>
\#include $<$ PString.h $>$
\#include $<$ DHT11.h $>$
int pin=19;
DHT11 dht11(pin);

The updated data every 1 minute is displayed on a database that is connected to a server computer with the SIM800L module using the General Packet Radio Service (GPRS) signal. The data display on the database can be viewed on the server computer by opening cpanel on google and accessing phpMyAdmin, but the database in phpMyAdmin can only be accessed by the server computer because it uses special access such as passwords and usernames. The database view is shown in Figure 3. 


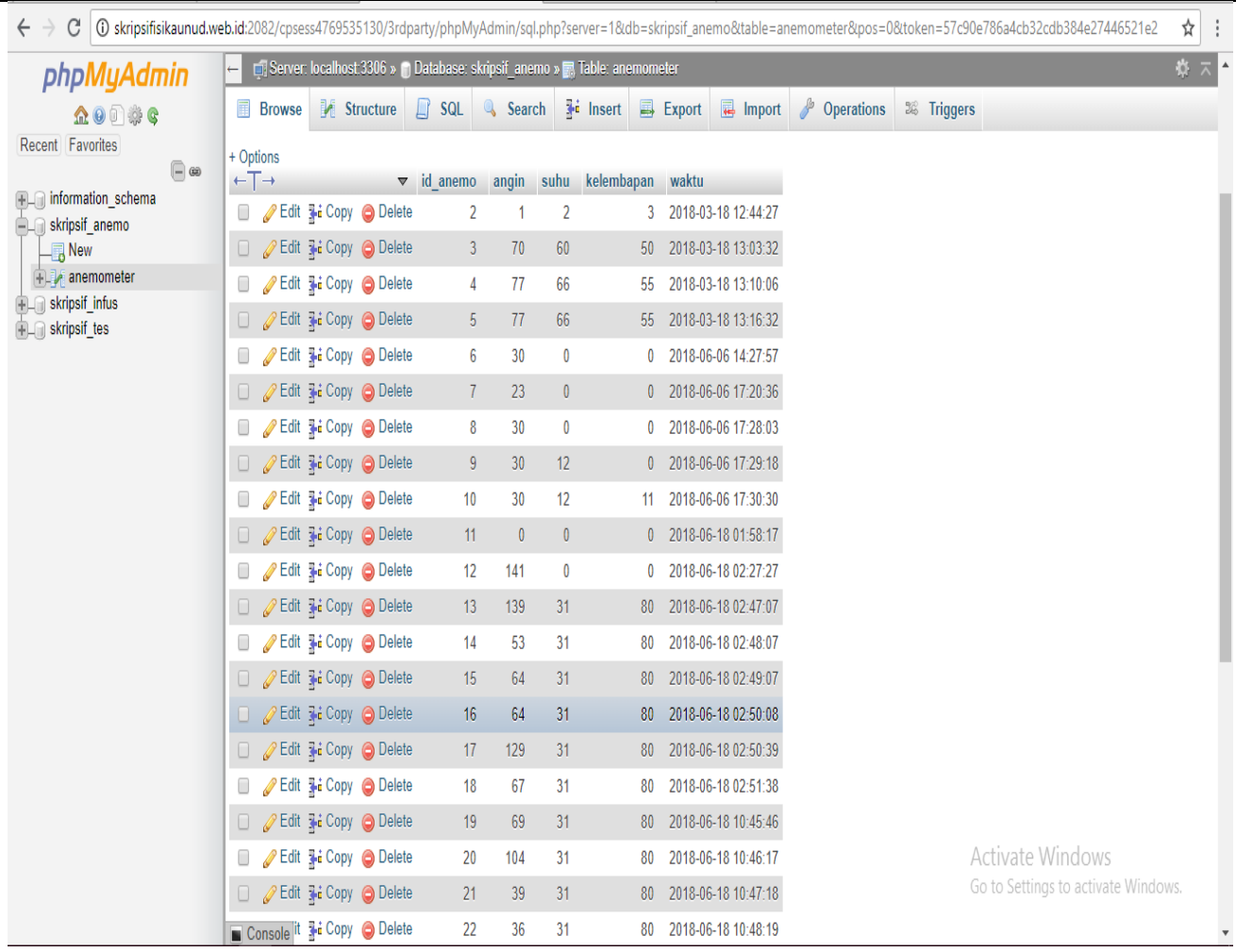

Figure 3. Database display

Display results of the measurement of wind speed data that can be accessed without using a password and username can be seen in Figure 4.

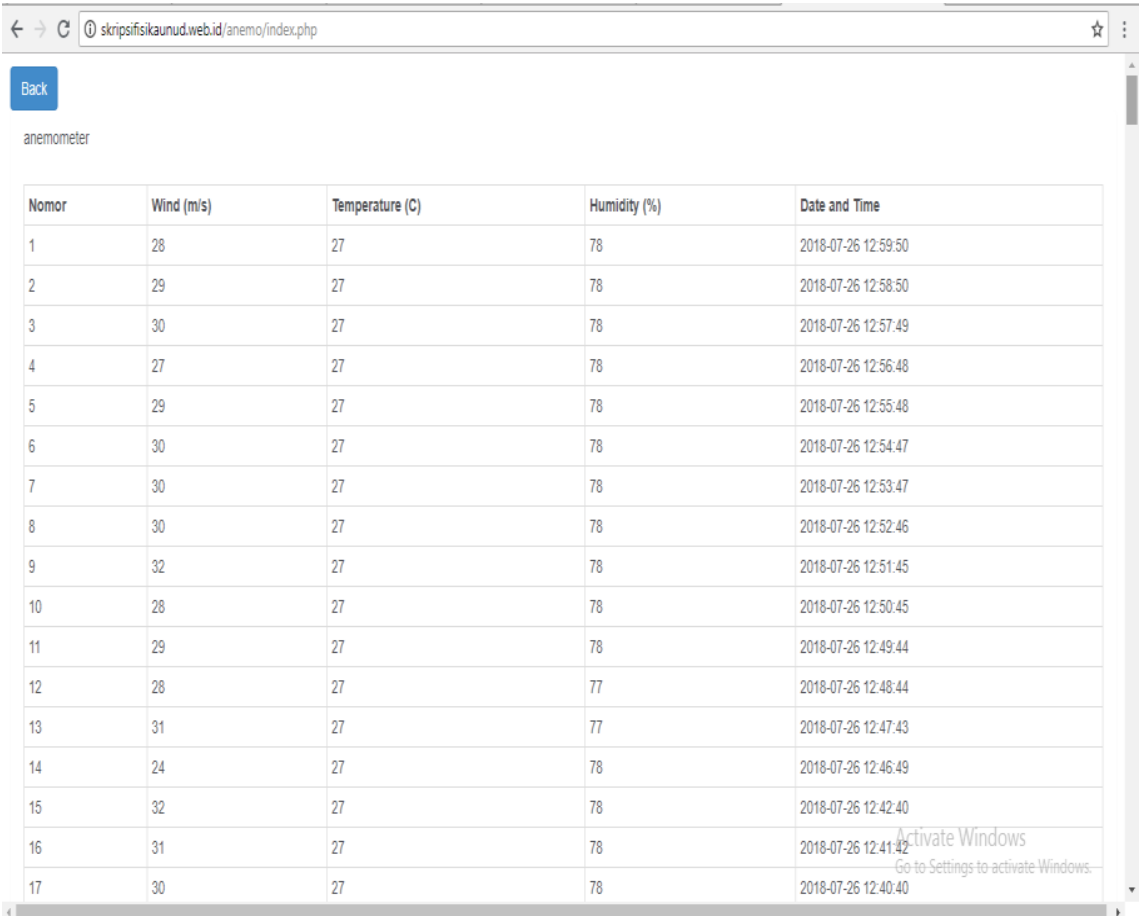

Figure 4. Display of wind speed measurement data

Poniman, S., Supardi, I. W., Mahayani, N. W. D., Artawan, M. D., \& Saputra, I. W. W. (2018). Web-based speed monitoring tools. International Journal of Physical Sciences and Engineering, 2(3), 36-42. 


\section{Conclusion}

From this research, it can be concluded that there are several things, namely: A web-based wind speed monitoring tool has been created. Anemometers require wind to rotate 3 propellers and produce data. Wind speeds generated by the anemometer can be monitored in real time.

\section{Acknowledgments}

Praise God, the writer offered the Presence of God Almighty because of His blessings and blessings the writer could complete this paper. On this occasion, we also did not forget to thank: Udayana University Chancellor as the fund holder, Udayana University Institute of Research and Community Service (LPPM) who provided the opportunity to carry out research, Dean of the Faculty of Mathematics and Natural Sciences, Udayana University, Physics Study Program, University Mathematics Faculty Udayana and Friends of the Physics Study Program Lecturer at Udayana University. 
References

Azlinaa, M. (2013). Pembuatan Alat Ukur Kecepatan Angin Dan Penunjuk Arah Angin Berbasis Mikrokontroller At-Mega8535. Saintia Fisika, 6(1).

Fatoni, A., Nugroho, D. D., \& Irawan, A. (2015). Rancang bangun alat pembelajaran microcontroller berbasis atmega 328 di universitas serang raya. Prosisko: Jurnal Pengembangan Riset dan Observasi Sistem Komputer, 2(1).

Hadi, A., Handajani, L., \& Putra, I. N. N. A. (2018). Financial Disclosure based on Web-ICT Determinants: Its Implications for Local Government Financial Performance in Indonesia. International Research Journal of Management, IT and Social Sciences (IRJMIS), 5(1), 72-85.

Hidayat, R. (2015). Pengaruh Motivasi, Kepemimpinan, dan Upah Terhadap Kinerja Karyawan di PT. Sri Rejeki Isman (Sritex) Unit Spinning III Sukoharjo (Doctoral dissertation, Universitas Muhammadiyah Surakarta).

Palupi, D. (2006). Uji Karakteristik Dimensi Sensor (Jari-jari) dari Cup Counter Anemometer.

Saputro, E., \& Wibawanto, H. (2017). Rancang Bangun Pengaman Pintu Otomatis Menggunakan E-KTP Berbasis Mikrokontroler Atmega328. Jurnal Teknik Elektro, 8(1), 1-4.

Sawita, I. K. A. S., Supardi, I. W., \& Adnyana, I. G. A. P. Alat Monitoring Suhu Melalui Aplikasi Android Menggunakan Sensor LM35 dan Modul SIM800L Berbasis Mikrokontroler ATMega16. BULETIN FISIKA, 18(2), 58-62.

Utama, Y. A. K. (2016). Perbandingan Kualitas Antar Sensor Suhu dengan Menggunakan Arduino Pro Mini. $e$ Jurnal Narodroid, 2(2), 145-150.

Poniman, S., Supardi, I. W., Mahayani, N. W. D., Artawan, M. D., \& Saputra, I. W. W. (2018). Web-based speed monitoring tools. International Journal of Physical Sciences and Engineering, 2(3), 36-42. 


\section{Biography of Authors}

\begin{tabular}{|c|c|}
\hline & $\begin{array}{l}\text { Ir. Poniman, M.Sc. was born Kediri, June 6, 1956, Address: Prasaman Univ } \\
\text { Udayana Blok F no: 43, Bukit Jimbaran, Badung Bali. Status: married, number of } \\
\text { children 3, Education: Bachelor of Physics, Faculty of Industrial Technology } \\
\text { Sepuluh Nopember Institute of Technology, Surabaya. Thesis title: Effect of Cast } \\
\text { Iron and Soft Steel Materials on Eddy Current Clad at Rotational Speed of Direct } \\
\text { Current Motors. S2: Physics of Post-graduate Materials for Electronic Materials } \\
\text { Bandung Institute of Technology, Bandung. } \\
\text { Email: sponiman@unud.ac.id }\end{array}$ \\
\hline & $\begin{array}{l}\text { I Wayan Supardi, Graduation Physics Graduate in Physics Study Program Faculty } \\
\text { of Mathematics Udayana University Year 1998, in the field of Instrumentation } \\
\text { Physics, Electronics, and Computers. Continuing S2 Studies at the Physics Study } \\
\text { Program Faculty of Mathematics Institute of Technology Bandung (ITB) graduated } \\
\text { in } 2003 \text { at Instrumentation Physics. The research that has been done in the field of } \\
\text { Instrumentation, Electronics, renewable energy, and Computing. } \\
\text { Email: supardi@unud.ac.id, supardi_wayan@yahoo.co.id }\end{array}$ \\
\hline & $\begin{array}{l}\text { Ni Wayan Dewi Mahayani, 9th-semester student in Physics Study Program } \\
\text { Faculty of Mathematics Udayana University, in the Field of Instrumentation } \\
\text { Physics, Electronics, and Computers. } \\
\text { Email : dewi.mahayani@student.unud.ac.id }\end{array}$ \\
\hline & $\begin{array}{l}\text { Ni Wayan Dewi Mahayani, 9th-semester student in Physics Study Program } \\
\text { Faculty of Mathematics Udayana University, in the Field of Instrumentation } \\
\text { Physics, Electronics, and Computers. } \\
\text { Email : made_dwi_artawan@student.unud.ac.id }\end{array}$ \\
\hline & $\begin{array}{l}\text { I Wayan Wisnawa Saputra, 9th-semester student in Physics Study Program } \\
\text { Faculty of Mathematics Udayana University, in the Field of Instrumentation } \\
\text { Physics, Electronics, and Computers. } \\
\text { Email: wisnawa.saputra@student.unud.ac.id }\end{array}$ \\
\hline
\end{tabular}

